\title{
Fluphenazine Hydrochloride
}

National Cancer Institute

\section{Source}

National Cancer Institute. Fluphenazine Hydrochloride. NCI Thesaurus. Code C47995.

The hydrochloride salt of fluphenazine, a phenothiazine with antipsychotic activity and potential antineoplastic activity. Fluphenazine blocks postsynaptic dopamine D2 receptors in the limbic system, cortical system and basal ganglia, resulting in a reduction of schizophrenia-associated hallucinations and delusions. In addition, as a serotonin antagonist, this agent may inhibit lymphocyte and myeloma cell proliferation by blocking 5-hydroxytrptamine type 1B (5-HT type 1B) receptors for serotonin. 